\title{
Response of Planktonic Rotifers to the Eutrophication Process and to the Autumnal Shift of Blooms in Lake Biwa, Japan. I. Changes in Abundance and Composition of Rotifers
}

\author{
Anna Hillbricht-IlkowsKa
}

\begin{abstract}
The density of planktonic rotifers in Lake Biwa was $100-3,000$ ind. $\cdot l^{-1}$ from September to December, 1980. This level is remarkably higher than that reported by Yамамото $(1967,1968)$ who noted no more than 10-600 ind. $\cdot l^{-1}$, although the northern basin (LBN) has been, in general, regarded as having lower values than the southern basin (LBS). An increase in population density was observed in the following species:

1) Small and fine particle feeders like Keratella cochlearis, Collotheca pelagica, Brachionus species group and $K$. quadrata and

2) graspers such as Polyarthra vulgaris and $P$. dolichoptera. The long-term changes may well be evidence for the accelerated eutrophication of Lake Biwa. The actual trophic difference between both basins is reflected in 1) greater abundance of rotifers (maximum value $=3,000$ ind. $\cdot l^{-1}$ ); 2 ) greater contribution of $K$. cochlearis (esp. f. tect $a=50 \%$ ); and 3) higher Trophic State Index (75) in the LBS; on the contrary, corresponding values were $300 \mathrm{ind} \cdot \cdot l^{-1}$, f. tect $a=1 \%$ and $\mathrm{TSI}=46$, respectively, in the LBN. During the autumnal shift of the blooms from green algae to diatoms coupled with the autumnal cooling of the water there was a succession of dominant species with food selection of different size particles: K. cochlearis, Polyarthra spp. K. quadrata. In November, a considerable increase in the number of $K$. cochlearis f. tecta was recognized.
\end{abstract}

\section{Introduction}

The abundance and composition of planktonic rotifers were found to be the good indicators of the trophic state of the lake expressed in terms of the amount of seston suspension or chlorophyll $a$ content or phytoplankton biomass (KARABIN, 1980; LANDNER, 1976). The rotifers are mostly suspension feeders filtering or sedimentating the fine particles directly into the mouth via water currents created by cirri. This manner of feeding is usually combined with the active seizing or grasping of the food items sometimes of the same or even greater size than the animal itself. Also the sucking way of feeding is rather widespread among typical planktonic rotifers, e.g. family Trichocercidae. Thus the rotifers can utilize particles widely ranging in size from smaller than $3 \mu \mathrm{m}$ like bacteria and detritus to the larger cells and colonial individuals of algae of ten up to $100 \mu \mathrm{m}$. This is why rotifers are believed to be better adapted to the trophic conditions in the pelagial habitat than the typical filter feeders like cladocerans. Thanks to their more flexible feeding behaviour (i.e. filtering and seizing or sucking), they can switch to any changes in the composition of the food suspension. In addition, the rotifers don't seem to suffer from the socalled "clogging" effect of the bigger, filamentous blue green algae or bigger dinoflagellates (GLIWICZ, 1977). Being generally of size smaller than the crustaceans, they are considered to be well protected from the intensive fish predation in the typical pelagial habitat (HILLBRICHTIlKowsKa, 1964; HillbRICHT-ILKOWSKA and WeglensKa, 1973).

These circumstances explain why the abundance of the rotifer fauna and its contribution to the whole zooplankton are both increasing with growing abundance and heterogeneity of the total suspension in the pelagial habitat. This trend of changes is observed quite commonly during the eutrophication process in the lowland, temperate lakes (KARABIN, 1980) as well as in 
the water bodies controlled by fish predation (Hillbricht-Ilkowska, 1964, 1978).

The aim of this study is to compare the general level of abundance and species composition of planktonic rotifers in both Lake Biwa basins versus their actual trophic differences as well as with the previous data from more than 10 years ago (Yамамото, 1967, 1968). The response of the rotifer community in terms of abundance and composition to the changes in the suspension abundance and composition coupled with the cooling process during the autumn 1980 will also be described.

\section{Study Area}

Lake Biwa, the largest lake in Japan (A-685 km², $Z_{\text {max. }}-103.6 \mathrm{~m}, \tilde{Z}-40.1 \mathrm{~m}, \quad \mathrm{~V}-$ $27.5 \mathrm{~km}^{3}$ ), offers the unique opportunity to study the relationship between the zooplankton community and the trophic patterns in the pelagial habitat. The lake is differentiated horizontally, being composed of two basins: the southern part (A-56. $8 \mathrm{~km}^{2}, Z_{\max }-7 \mathrm{~m}, \overline{\mathrm{Z}}-2.8 \mathrm{~m}, \mathrm{~V}-0.16$ $\mathrm{km}^{3}$ ) and the northern one $\left(\mathrm{A}-628 \mathrm{~km}^{2}\right.$, $Z_{\text {max. }}-103.6 \mathrm{~m}, \tilde{Z}-43.5 \mathrm{~m}, \mathrm{~V}-27.3 \mathrm{~km}^{3}$ ).

The southern part of Lake Biwa (here called LBS for convenience) is shallow, close to the outlet and surrounded by compact urban areas. It has a distinctly eutrophic character. The northern part of Lake Biwa (here called LBN for convenience) has a mesotrophic character bordering the oligotrophic. Both parts differ greatly in respect to the abundance of phytoplankton (i.e., biomass or chlorophyll $a$ content), although the seasonal pattern and dominant succession are rather similar.

According to Negoro (1967, 1968), MorI (1971), WAKABAYASHi and ICHISE (1980), ICHISE and WAKABAYASHI (1980) and Miura (Mori, ed. 1980), the seasonal succession of dominants among the phytoplankton is as follows: from December to March such diatoms as Melosira italica, M. solida and Fragilaria crotonensis are dominant among the phytoplankton of both basins; from March to September a bloom of the green alga Staurastrum dorsidentife- rum occurrs especially in the LBN, along with Closterium aciculare and Pediastrum biwae especially in the LBS. From April to May occasionally Asterionella formosa co-dominates together with Melosira sp. div.; this diatom also appears in the autumn. The other species like Cyclotella glomerata, Dinobryon divergens, Nitzschia acicularis and Cryptomonas sp. occasionally appear in large number (ICHISE and WAKABAYASHI, 1980) especially in the LBS.

The concentration of nutrients and the phytoplankton biomass undergo multiannual changes which are connected with the eutrophication process; they are faster in the LBS, slower in the LBN.

The highest quantity of net phytoplankton reported in surface waters by NEGORO (1967, 1968) and Mori (1971) for the years 1965-1970 ranged from 10 to $200 \times 10^{3}$ cells (including colonies) per liter in late autumn, winter or early summer, differently from year to year in both basins. According to WAKABAYASHI and ICHISE (1980), the highest quantity estimated in non-filtered samples and reported for 1978-1979 years reached the value of $2000 \times 10^{3} \mathrm{cells} \cdot l^{-1}$ in the LBN in late autumn and about $6000 \times$ $10^{3}$ cells $\cdot l^{-1}$ in the LBS in May. The data between the two periods (i.e., 1965-1970 and 1978-1979) cannot be compared directly because of the different method of collection, but one finds that Fragilaria crotonensis was reportedly quite scarce in 1965-1970, whereas a decade later it was the dominant species in the winter phytoplankton.

Some other changes in the species composition of phytoplankton were also reported. In 1970 the appearance of blue-green algae was noted, like Lyngbya limnetica, Anabaena macrospora, Aphanotheca alathrata, and Microcystis aeruginosa, mainly in the LBS but also in the LBN (MIURA, in Mori ed. 1980). Since 1977 the "red tide" of the chrysophyte Uroglenopsis americana occurred in early summer in both basins (MIURA, in MOrI ed. 1980). In May 1979, according to ICHISE and WAKABAYASHI (1980) this species num- 
bered 6000 cells in $\mathrm{m} l$ and almost $34.3 \mu \mathrm{g}$ of chlorophyll $a$ per liter. According to MORI (1980) in the 1950's a dramatic decrease of Secchi disc readings was noted even in the LBN, and from 1970 also there was a noticeable increase of total-P and total- $\mathrm{N}$ concentrations. The values of chlorophyll $a$ content in summer were almost tripled in the LBN during the period 1963-1976 (MORI, 1980). According to ICHISE and WAKABAyAshi (1980) the maximal content of chlorophyll $a$ was close to $30-35 \mathrm{mg} \cdot \mathrm{m}^{-3}$ in the LBS in May 1979. The similar level of chlorophyll $a$ was found by NARITA (unpublished data) in the same season and basin; nevertheless, values exceeding $40 \mathrm{mg} \cdot \mathrm{m}^{-3}$ were found in some bays and stations close to shore.

InOue et al. (1980) reported that the lake received about 4609 tons of nitrogen in 1975 of which nearly the half is exported via main outlet. Of the total 487 tons of phosphorus, about two thirds is retained annually in the lake system. About 50\% of the total-N load and about $78 \%$ of the total-P load come from the urban areas in the form of domestic sewage and industrial wastes.

\section{Methods}

Two stations in the LBN were chosen: St. I is about $80 \mathrm{~m}$ in depth, while St. II located southwards is about $70 \mathrm{~m}$ in depth (Fig. 3). Six stations were chosen in the LBS: St. I is close to the outlet and to the compact urban areas (depth $=2.6 \mathrm{~m}$ ), St. II $(\operatorname{depth}=4.2 \mathrm{~m})$, St. III (depth $=$ $4.5 \mathrm{~m})$ and St. IV $($ depth $=4.3 \mathrm{~m})$ represent the main off-shore basin of the LBS successively northwards (Fig. 3). Station V is one of the shallow bay and the place of the pearl culture $($ depth $=1.6 \mathrm{~m})$. Station VI (depth $=6.5 \mathrm{~m}$ ) is located close to the boundary region between both basins of Lake Biwa and therefore is much more affected by the water masses of the LBN.

The samples were taken on four occasions (i.e., September 5, October 16, November 13 and December 14) in the LBS and on three occasions (October 1, October
23 and December 12) in the LBN. Following the recommedations by the Plankton Ecology Group given in Botrell et al. (1976), the samples were taken from $1 \mathrm{~m}$ intervals in the LBS and $2-3 \mathrm{~m}$ intervals in the LBN; then they were poured into one bottle. The samples represent the plankton in the whole water column in the LBS and in the epilimnion (0-15 m layer) in the LBN. The water sampler of the volume of $40 l$ of Patalas design was used as well as $45 \mu \mathrm{m}$ mesh size net for concentration. This net was tested to retain at least $80 \%$ of the rotifers of the body size greater than $80-100 \mu \mathrm{m}$, but was insufficient for very small rotifers of $60 \mu \mathrm{m}$ in size like Anureopsis sp. div. (Botrell et al., 1976). The samples were fixed firstly with Utermöhl's solution to prevent the advanced contraction of the animals soft bodies and then with $4 \%$ formaline. The Secchi disc readings (SD readings) and water temperature measurements were made on the same occasions. The samples taken from the lake were examined under the microscope following the procedure recommended by the Plankton Ecology group (BotRELl et al., 1976). The rotifers were identified at the species level and the number of individuals was counted. Morphological forms of Keratella cochlearis (Gosse) were distinguished (i.e., forma cochlearis with posterior spine and forma tecta without posterior spine). Rough estimations of the abundance and composition of the seston were made in a similar way.

\section{Results and Discussion}

\section{4-1. Environmental conditions during the study period}

The study period (i.e., from September to December 1980) can be briefly characterized by the period of the shift from one blooming condition to the other coupled with the steady decrease of temperature and the increase of turbulence (mixing) both reflected in the high values of the cooling rates (Fig. 1, Table 1 ).

In September, the temperature in the 


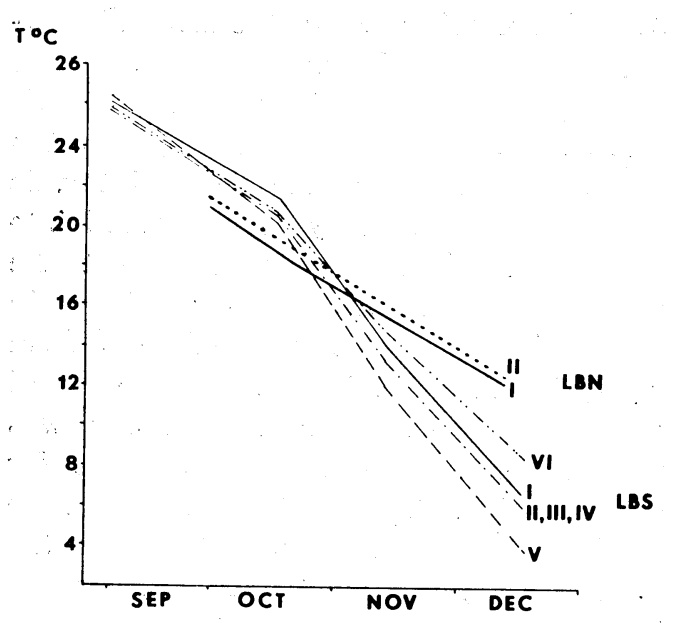

Fig. 1. The changes of the temperature in the epilimnion (0-15 $\mathrm{m}$ ) at two stations in the northern basin and in the whole water column at six stations in the southern basin of Lake Biwa, from September to December 1980.

LBN: Northern basin of Lake Biwa

LBS: Southern basin of Lake Biwa

LBS was still high (above $25^{\circ} \mathrm{C}$ ) without any visible stratification even at the deepest St. VI; the highest value was noted at St. $\mathrm{V}$ (Fig. 1). In the LBN, the water temperature of the epilimnion was about $4^{\circ} \mathrm{C}$ lower than the respective values for the LBS; the thermocline was at a depth of $15 \mathrm{~m}$. Starting from October, when the cooling rates increased (Table 1), the water temperature at each station differed according to the depth-volume relations. In December, the water at St. V in the
LBS was the coolest, with the warmest at St. VI in the LBS and at both stations in the LBN (Fig. 1). The cooling rate for the large and deep LBN was fairly uniform throughout the study period (i.e., 0.10 $0.14^{\circ} \mathrm{C}$ per day) (Table 1 ). On the other hand, in the shallow LBS, there was a steady increase of the cooling rate from $0.11-0.15^{\circ} \mathrm{C}$ in September and October to $0.20-0.26^{\circ} \mathrm{C}$ per day in November and December (Table 1).

According to OKUDA (MoRI ed. 1980), in the autumn period the warm surface waters in the LBN flow into the LBS via the boundary region. This is probably why the water at St. VI located close to this boundary was warmest in December and November and the most transparent as well; it had the lowest cooling rates of all stations in the LBS (Fig. 1, Table 1).

SD readings in $m$ taken on each occasion and at each station were transformed logarithmically into the Trophic State Index (TSI) according to CARLSON's formula (CARLSON, 1977):

$$
\mathrm{TSI}=10\left(6-\frac{\ln \mathrm{SD}}{\ln 2}\right)
$$

Where SD is expressed in meters.

This index is used mainly for comparing the trophic differences of the whole lake systems but can be used also to assess any trophic difference in time and space as far as it concerns the total amount of seston reflected in the SD readings.

Table 1. The cooling rate (in ${ }^{\circ} \mathrm{C}$ per day) of the lake water at six stations in the southern basin (LBS) and of the epilimnion (0-15 m) at two stations in the northern basin of Lake Biwa, from September to December 1980.

\begin{tabular}{c|c|c|c|c|c|c|c|c}
\hline \multirow{2}{*}{$\begin{array}{c}\text { Sampling } \\
\text { date }\end{array}$} & \multicolumn{9}{|c|}{ LBS } & \multicolumn{2}{c}{ LBN } \\
\cline { 2 - 8 } & I & II & III & IV & V & VI & I & II \\
\hline Sept. 5 & & & & & & & & \\
Oct. 16 & 0.11 & 0.13 & 0.13 & 0.13 & 0.15 & 0.13 & 0.12 & 0.10 \\
Nov. 15 & 0.19 & 0.19 & 0.19 & 0.18 & 0.21 & 0.14 & & \\
Dec. 14 & 0.24 & 0.23 & 0.23 & 0.26 & 0.25 & 0.20 & 0.13 & 0.14 \\
\hline
\end{tabular}

Note: The cooling rate was calculated by dividing the difference in temperature before and after sampling interval by the length of this period. The respective values are placed between the dates of sampling. 
According to CARLSON (1977) the TSI values from 10 to 30 can be attributed to oligotrophic conditions, from 35 to 50 for more or less mesotrophic, from 50 to 65 for fairly eutrophic and more than 65 for highly eutrophic conditions.

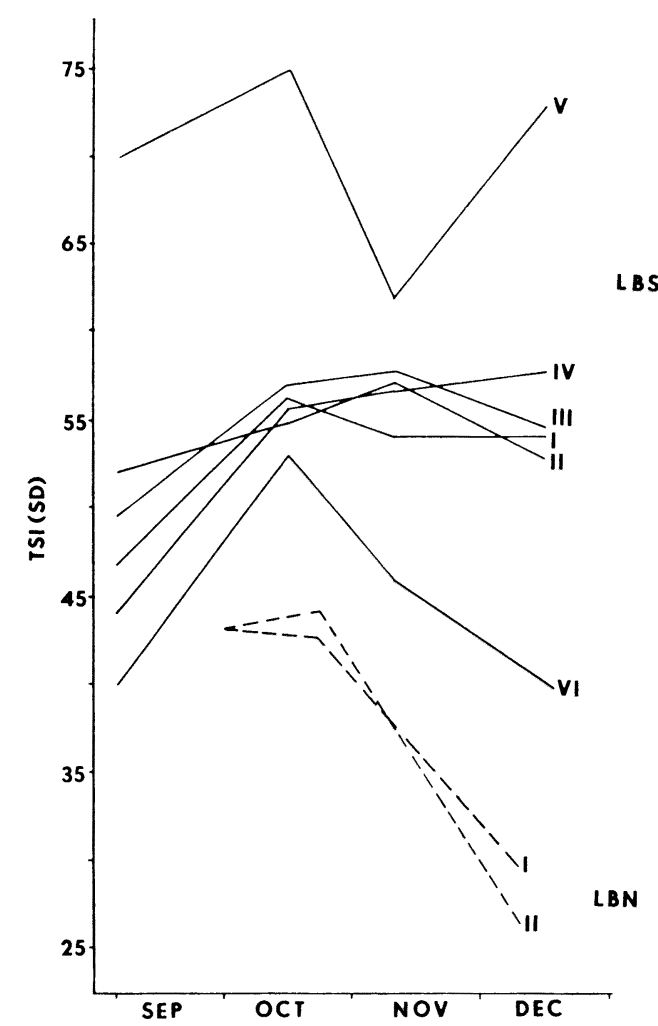

Fig. 2. The changes of the Trophic State Index (TSI) according to CARLSoN (1977) and based on Secchi disc readings at two stations in the northern basin (LBN) and at six stations in the southern basin (LBS) of Lake Biwa from September to December 1980.

The lowest transparency, i.e., the highest TSI values (63-75) were reported for St. V in the LBS during the whole study period (Fig. 2). The transparency of the water at this station was as much as $2-3$ times lower than that for both stations in the LBN, in which the TSI value around 42 at the beginning of October dropped to 25-30 in December (Fig. 2). The TSI values found at each station (I, II, III and IV) in the LBS ranged from 40 to 52 in
September but became a little higher (5056) at the beginning of the next month (Fig. 2.) This indicates that the water masses of the main body of the LBS became more turbid and less transparent. St. VI, located near the boundary region between the LBS and the LBN, generally showed the same changes observed in the LBN (Fig. 2).

The rough microscopic examination of the samples revealed that in September and October in both basins of Lake Biwa the colonies of Pediastrum biwae and Staurastrum dorsidentiferum dominated the phytoplankton with some visible admixture of Closterium aciculare and $\mathrm{Me}$ losira italica (Table 2). The abundance of $S$. dorsidentiferum seemed to be at the same level with that of Pediastrum biwae during September in the LBS, but was clearly more abundant in October in both basins (Table 2). In November a considerable amount of detritus aggregates appeared in the samples taken from the LBS, but there were no data from the LBN. One can assume that the resuspension of the bottom sediments was mainly responsible for the occurrence of the detritus in the shallow LBS. In December the cells and colonies of $S$. dorsidentiferum and $P$. biwae became rare and Fragilaria crotonensis dominated the phytoplankton, together with Closterium aciculare and Melosira italica.

The peculiar exception from this seasonal succession of dominating algal species was found at St. V in which no comparable amount of $S$. dorsidentiferum was found throughout the study period. As to seston at this station mainly $P$. biwae dominated in September and October together with a great amount of detritus throughout the period under study. In December, Fragilaria crotonensis became dominant like at other stations in the LBS. The constant resuspension of the bottom sediments are mainly responsible for the permanently lower transparency of the lake water at St. V $\quad($ depth $=1.6 \mathrm{~m})$.

The measurements of the chlorophyll 
Table 2. Rough assessment of the relative abundance of the algal species and detritus at six stations in the southern basin (LBS) and at two stations in the northern basin (LBN) of Lake Biwa from September to December 1980.

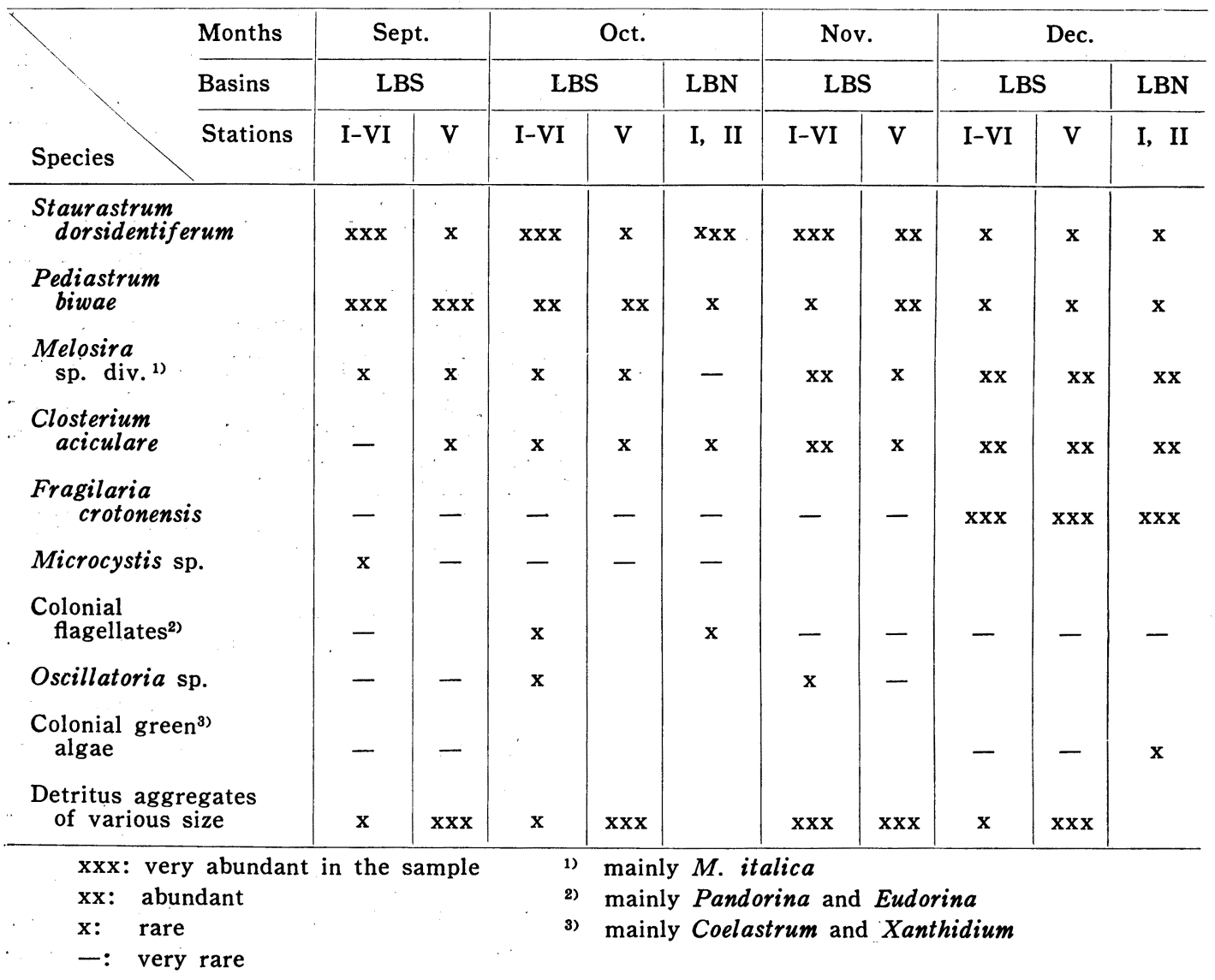

$a$ concentration obtained in the LBS in November revealed values around $20-30$ $\mu \mathrm{g} \cdot l^{-1}$ at St. II, III and IV. About half of this amount is confined to the particles smaller then $25 \mu \mathrm{m}, i . e$, directly accessible to the plankton filter feeders (Table 3 ). At St. V, the small edible particles account for about $74 \%$ and the total amount of chlorophyll $a$ exceeds $30 \mu \mathrm{g} \cdot l^{-1}$. At both stations in the LBN and at St. VI in the LBS, the amount of chlorophyll $a$ is $2-3$ times smaller. The edible fraction is significantly smaller than at the remaining stations in the LBS (Table 3).

The significant contribution of the small particles to the total amount of the chlorophyll $a$ reported for November (i.e., the period of detritus appearance in the pelagial habitat) suggests that the nanoplankton are another important component of the seston. This can be confirmed with the data on the seasonal changes of the ratio of the size fraction of chlorophyll $a$ up to $25 \mu \mathrm{m}$ to the total amount of chlorophyll. These data are for 1978 in the LBS. This ratio has the lowest value $(0.3-0.4)$ in August and September, and it is constantly increasing during October reaching about 0.7 in the first half of November. In the second half of November it drops again to 0.5 but at the beginning of December it rapidly increases, to reach 0.8 in January 1979. In the period from January to June this ratio usually fluctuates around $0.7-$ 0.9. Therefore, it can be said that from September to December the contribution 
Table 3. The total amount of chlorophyll $a$ in November 1980, calculated according to Lorenzen's formula and its percentage found in the seston fraction up to $25 \mu \mathrm{m}$ at six stations in the southern basin (LBS) and at two stations in the epilimnion in the northern basin (LBN) of Lake Biwa (from unpublished data of T. NARITA).

\begin{tabular}{l|c|c}
\hline Stations & $\begin{array}{c}\text { Total } \\
\left(\mu \mathrm{g} \cdot l^{-1}\right)\end{array}$ & $\begin{array}{c}\text { Percentage in } \\
\text { seston size } \\
\text { fraction up to } \\
25 \mu \mathrm{m}(\%)\end{array}$ \\
\hline LBS & & \\
I & 13.84 & 54 \\
II & 22.20 & 38 \\
III & 29.79 & 48 \\
IV & 24.03 & 50 \\
V & 32.49 & 74 \\
VI & 5.09 & 55 \\
\hline LBN & & \\
I & 5.09 & 41 \\
II & 4.32 & 19 \\
\hline
\end{tabular}

of the nanoplankton rapidly changes from its lowest values in summer to its highest values in winter (i.e., along the shift of the algal blooms described above).

4-2. Abundance and species composition of rotifer community versus previous data

The abundance of rotifers in the autumn 1980 was compared with the data for the relevent periods of $1965-67$ reported by YамAMOTO (1967, 1968).

In the autumn of 1980 planktonic rotifers in the LBS numbered several hundred to a few thousand individuals per liter which was one to two orders of magnitude higher than the level reported by YамAмото a decade earlier (Table 4). Evidently, it is partly due to the different sampling method and different mesh size in the net used. YАМАMОТО used a plankton tow net with a mesh size of about $75 \mu \mathrm{m}$ (i.e., almost twice larger than used in the present study). BOTRELL et al. (1976) reported that through the plankton net of $75 \mu \mathrm{m}$ mesh size pass at least $50 \%$ of the original number of rotifers and even more of the small-size species or eggs. For rough comparison the data from the period 1965-1967 have to be multiplied by two. With this doubling there was still a marked increase in the number of rotifers in 1980 in comparison with 1965-1967 in relevent months Table 4).

The species composition was almost the same in both periods. The most numerous in the autumn months of 1965-1967 and 1980 were Keratella cochlearis and Polyarthra vulgaris with Pol. dolichoptera*. Conochilus dossuarius, Brachionus angularis, Filinia longiseta and Synchaeta sp. div. (Syn. oblonga, Syn. grandis, Syn. pectinata) occasionally (September, October) were occurring in large numbers. Pleosoma truncatum, Trichocerca sp. div. (Tr. birostris, $T r$. capucina, and $T r$. pusilla) were common in these periods but not numerous. The species of the genus Brachionus ( $\mathrm{Br}$. diversicornis, $\mathrm{Br}$. falcatus, $\mathrm{Br}$. calyciflorus, $\mathrm{Br}$. quadridentatus) are usually reported for particular occasion and station (Table 4). However, there is a difference between the species composition in 1965-1967 and in 1980. Pompholyx complanata was rather numerous in the period 1965-1967, while in 1980 only a few individuals were found (Table 4). The few individuals of $A s$ planchna priodonta were noted in 1980, whereas a decade ago they were reportedly numerous (Table 4). On the other hand, in 1980 the domination of $K$. quadrata was observed in November and December in the LBS as well as the occurrence of $\mathrm{Br}$. calyciflorus and Collotheca pelagica at some stations and months. The last two species were not found at all by ҮАмАмото in autumn 1965-1967 (Table 4).

Generally, the same changes in the number and composition of rotifers occurred in the LBN. The number found in 1980 was an order of magnitude higher than the corrected data for a decade earlier. The bulk of the community was composed

\footnotetext{
- It is practically impossible to differentiate the species of Polyarthra and Synchaeta genus in the fixed sample when these species coexist. Due to a slight difference in size (however distorted in the fixed sample) Pol. vulgaris constantly dominated polyarchids (about $80 \%$ ) and small-size Syn. oblonga dominated synchaetas.
} 


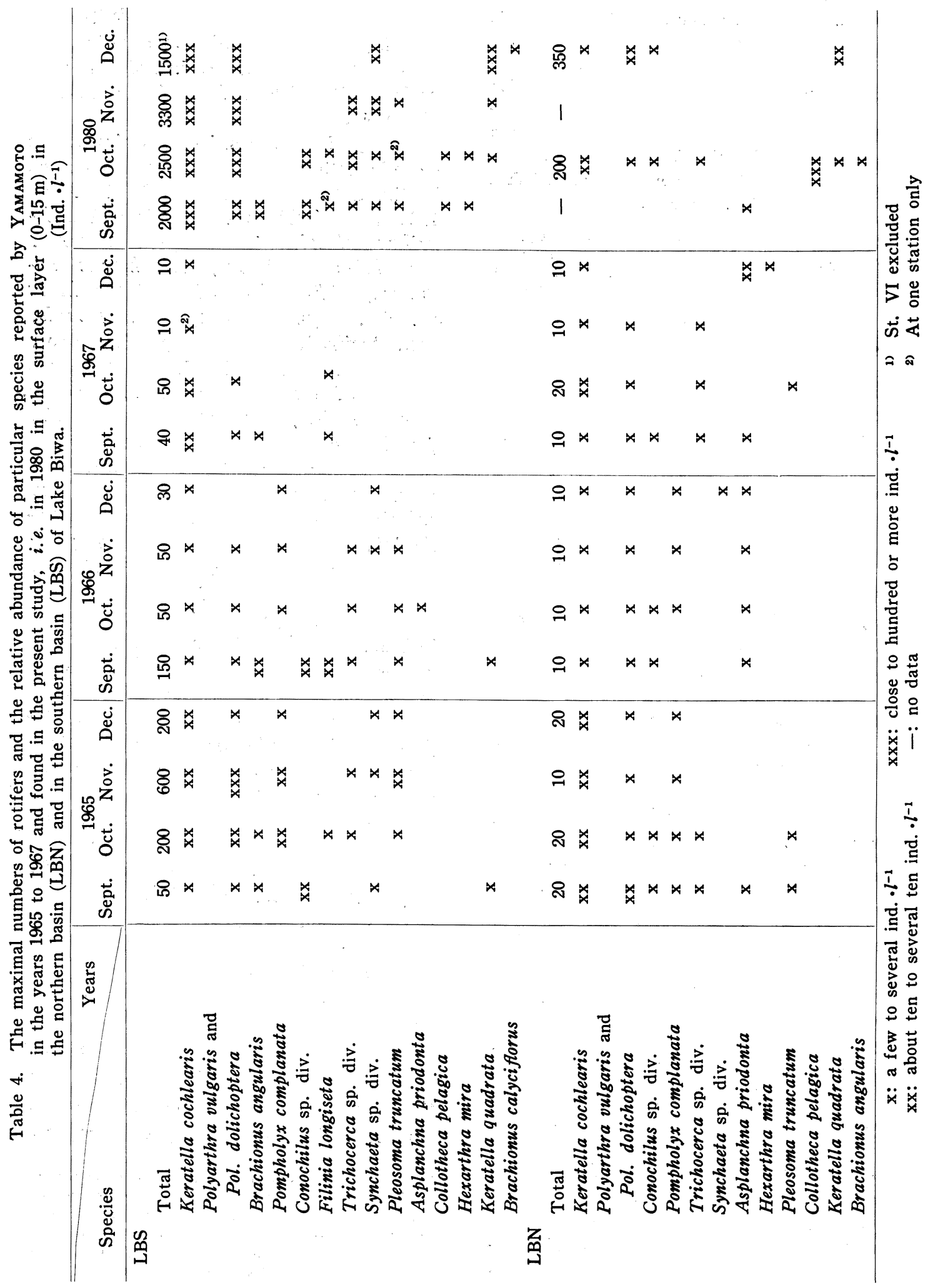


of the same species, i.e., $K$. cochlearis, Pol. vulgaris, but in 1980 there was no Pompholyx complanata replaced possibly by K. quadrata and Coll. pelagica. The latter species dominated the rotifer community in October in the LBN (Table 4), which was not noted by Yamamoto.

The abundance of rotifers close to the one found in the present study was reported also by WAKABAYASHI and ICHISE (1980) and ICHISE and WAKABAYASH (1980) in both basins of Lake Biwa in 1978 and 1979. In the LBN the abundance of rotifers varied between $200-300$ ind. $\cdot l^{-1}$ in October and December, and Polyarthra spp. with $K$. cochlearis were the dominants; while in the LBS rotifers exceeded 1000 ind. $\cdot l^{-1}$ and evidenced the same domination pattern (ICHISE and WAKABAYASHI, 1980).

4-3. Distribution, dynamics and trophic composition of the rotifer community

The abundance of the plankton rotifers in the LBN was found to be an order of magnitude lower than in the LBS in respective months (Fig. 3, Table 5 ). The values of $1000-2000$ ind. $\cdot l^{-1}$ commonly noted in the LBS during study period indicate that this basin is highly eutrophic. The largest values close to 3500 ind. $\cdot l^{-1}$ were noted near the outlet, at Otsu City and at St. V, in a shallow, turbid lake bay (Fig. 3). The smallest numbers occurred at St. VI close to the boundary with the LBN. In the LBN the values ranged $100-200$ ind. $\cdot l^{-1}$ and confirmed the mesotrophic character of this basin in the lake (Fig. 3, Table 5). There were fewer rotifers at all stations in October compared with September, followed by an increase in November and another decrease in December (Fig. 3).

The rotifer species occurring during the study period may be differentiated according to food preference and feeding habits.

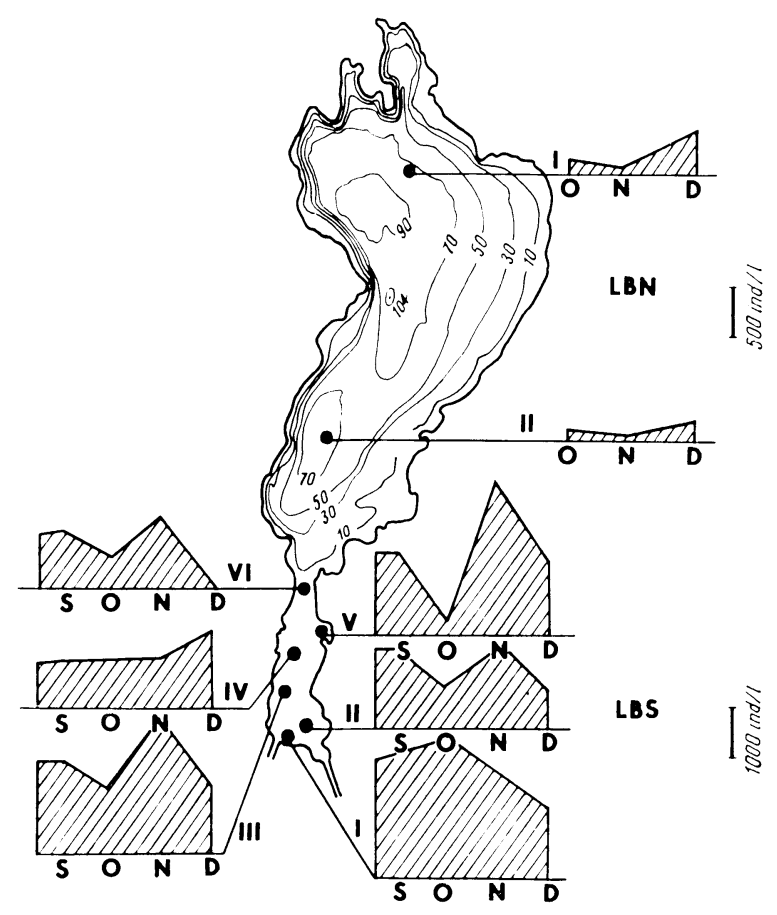

Fig. 3. The changes of the abundance of planktonic rotifers at two stations in the northern basin (LBN) and at six stations in the southern basin (LBS) of Lake Biwa, from September to December 1980. Note the different scale for the LBN and the LBS. S: Sept., O: Oct., N: Nov., D: Dec. 
Table 5. The average numbers of rotifers and the range found in the study period at six stations in the southern basin (LBS) and in the epilimnion at two stations in the northern basin (LBN) of Lake Biwa.

(Ind. $\cdot l^{-1}$ )

\begin{tabular}{l|cccccc|rr}
\hline & I & II & III & LBS & IV & V & VI & \multicolumn{2}{|c}{ I } & II \\
\hline \multirow{2}{*}{ Range } & 2700 & 2150 & 2700 & 1400 & 3300 & 1300 & 340 & 200 \\
& 1 & 1 & $l$ & $l$ & $l$ & $?$ & 60 & 60 \\
& 1600 & 1000 & 1400 & 750 & 350 & 90 & 185 & 145 \\
\hline \multirow{3}{*}{ Average } & 2300 & 1550 & 1800 & 1020 & 1750 & 750 & 185 \\
\hline
\end{tabular}

One can distinguish six trophic groups according to the manner of feeding (filter* ing, grasping), and the size and nature of the prefered food particles (POURRIOT, 1965; KARABIN, 1980).

The first group includes fine filter feeders like $K$. cochlearis, $B$. angularis, Con. dossuarius, Filinia longiseta, Coll. pelagica feeding on the very minute particles (below $5 \mu \mathrm{m}$ ) like detritus and bacteria.

The second group includes also the filter feeders but collecting a bit larger particles (up to $10 \mu \mathrm{m}$ in size) including some small algae like Chlorococcales, Volvocales and Euglenoides. Many species of the genus $\mathrm{Bra}$ chionus and $K$. quadrata belong to this group.

The third group includes the graspers like the species of the genus Polyarthra which are actively seizing the food particles as big as $20-30 \mu \mathrm{m}$ in size and also filtering the smaller ones (Cryptomonas, Chrysomonas and related algae).

The fourth group includes the suckers like the genus Trichocerca which can utilize the algal cells in the wide range of size, including some colonial forms.

The fifth group includes the larger graspers like the genus Synchaeta, which can feed on food items as big as $50 \mu \mathrm{m}$. Usually the flagellates and diatoms are eaten, but occasionally even the animal food.

The sixth group includes typical predators like Pleosoma truncatum and Asplanchna sp. div., which actively seize food items mainly other animals, among them also are other rotifers like Keratella, Polyarthra and Synchaeta.

There was the regular shift in the trophic composition of the rotifer community in the study period, and it was more or less similar in both basins and at all stations (Fig. 4).

Fine particle feeders (group 1) dominated in September in the LBS, especially $K$. cochlearis, the number of which was 7161687 ind. $\cdot l^{-1 *}$. In October there was a codomination of $K$. cochlearis (113-1132 ind. $\left.\cdot l^{-1}\right)$ with Pol. vulgaris and Pol. dolichoptera (249-1175 ind. $\left.\cdot l^{-1}\right)$. These last two species are typical graspers with a preference for small algae (group 3). In November this group entirely dominated the rotifer community (643-2346 ind. • $\left.l^{-1}\right)$. In December these small graspers codominated again (649-911 ind. $\cdot l^{-1}$ ) with filter feeders like $K$. quadrata (275-572 ind. $\left.\cdot l^{-1}\right)$; the latter belongs to the second group (Fig. 4). K. quadrata is almost twice larger than $K$. cochlearis (respective size: $100-150 \mu \mathrm{m}$ and $150-300 \mu \mathrm{m})$ and is believed to be cold-liking and more efficient in collecting relatively larger particles like algal cells as well as very minute ones like detritus.

In the LBN, at the beginning of the study period (October) the most numerous fine particle feeder (group 1) was Coll. pelagica (51-111 ind. $\left.\cdot l^{-1}\right)$, which codominated together with $K$. cochlearis (20-30 ind. $\left.\cdot l^{-1}\right)$. Generally, the occurrence of Coll. pelagica was more significant in the LBN than in the LBS. In December there was the domination of Polyarthra genus (175-309 ind. $\cdot l^{-1}$ ) at both stations of the LBN, and only a few individuals of

- Hereinafter (in brackets) the range for the stations $\mathrm{I}-\mathrm{V}$ in the LBS is given as well as for two stations in the LBN in the appropriate places. 


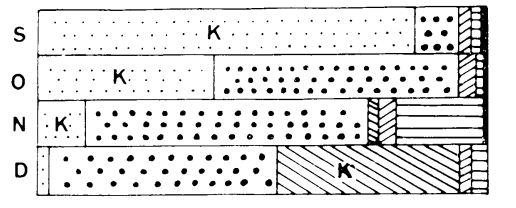

LBS $\mathrm{I}, \mathrm{II}, \mathrm{III}, \mathrm{IV}, \mathrm{VI}$

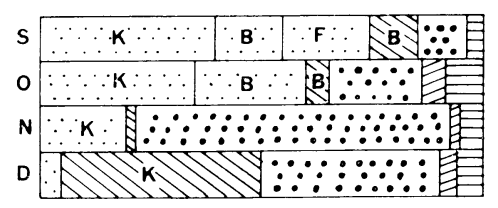

LBS

V

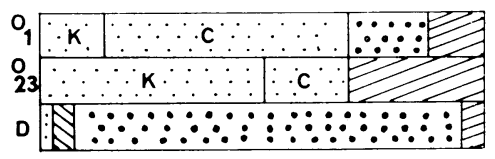

LBN

I,II

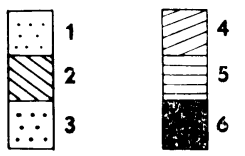

Fig. 4. The percentage distribution of the trophic groups and species in the total numbers of planktonic rotifers at six stations in the southern basin (LBS) and at two stations in the northern basin (LBN) of Lake Biwa.

1. fine particle filter feeders (bacteria, detritus); Keratella cochlearis, Brachionus angularis, Conochilus dossuarius, Filinia longiseta, Collotheca pelagica.

2: small particle filter feeders (detritus, small algae); K. quadrata, Brachionus sp. div.

3: graspers (small algae); Polyarthra sp. div.

4: suckers (small and bigger algae); Trichocerca sp. div.

5: graspers (bigger algae); Synchaeta sp. div.

6: predators (animal food); Pleosoma sp. div.

K: Keratella, B: Brachionus, F: Filinia, C: Collotheca,

S: September, O: October, N: November, D: December

$K$. quadrata (9-13 ind. $\cdot l^{-1}$ ) were found (Fig. 4). There seems to be some delay in the succession of dominants in the northern basin of Lake Biwa compared with the southern one.

Sucking herbivores like Trichocerca sp. div. (Tr. birostris, Tr. capucina, Tr. pusilla, Tr. cylindrica) consisted of about $10 \%$ of the rotifer community and occurred in number up to $100 \mathrm{ind} \cdot l^{-1}$ in the LBS and up o 20 ind. $\cdot l^{-1}$ in the LBN. The most numerous was $T r$. birostris which appeared in the whole study period.

In November, together with the domination of the genus Polyarthra, there was the marked increase of the number of Synchaeta sp. div. (202-634 ind. $\left.\cdot l^{-1}\right)$ in the LBS basically of the similar feeding behaviour (group 5) but with the possibility of grasping quite large food items (Fig. $4)$.

The rotifer community in a shallow bay (St. V) in the LBS offered another interesting exception (Fig. 4). In September and October, when the bay was relatively unaffected by Staurastrum dorsidentiferum bloom (see proceeding chapter) several species of the genus Brachionus contributed significantly to the total abundance of rotifers. These filter feeders (group 1 and 2) occurred in numbers up to $300 \mathrm{ind} \cdot l^{-1}$ and mainly belonged to $\mathrm{Br}$. angularis, $\mathrm{Br}$. falcatus, $B r$. diversicornis, $B r$. forficula and $\mathrm{Br}$. quadridentatus. At St. V, Filinia longiseta (group 1) were found in numbers close to 300 ind. $\cdot l^{-1}$ (Fig. 4).

The typical predatory component did not seem to play a significant role in the rotifer community in the study period. Only a few specimens from the genus $A s$ planchna were found. However, Pleosoma truncatum occurred permanently (except in December) in numbers below 10 ind. $\cdot l^{-1}$ (Fig. 4). Its main food according to POURRIOT (1965) are the individuals of Polyarthra and Synchaeta.

$K$. cochlearis is one of the smallest (ranging in size up to $150-200 \mu \mathrm{m}$ ) component of the zooplankton and is believed to be the most widespread and ubiquitous animal species in the world. It is also one of the most polymorphic (PEJLER, 1980). This species in general and its forma tecta 
Table 6. The numbers of Keratella cochlearis forma tecta and its contribution (\%) to the Keratella cochlearis population in the southern (LBS) and northern (LBN) basins of Lake Biwa in October and December 1980. Range for six stations.

\begin{tabular}{l|c|c|c|c}
\hline \multirow{2}{*}{ Basins } & \multicolumn{2}{|c|}{ Oct. } & \multicolumn{2}{c}{ Dec. } \\
\cline { 2 - 5 } & $\left(\right.$ Ind. $\left.\cdot l^{-1}\right)$ & $(\%)$ & (Ind. $\left.\cdot l^{-1}\right)$ & $(\%)$ \\
\hline LBS & $5-60$ & $1-6$ & $1-5$ & $1-11$ \\
LBN & $1-21$ & $0.1-1$ & 0 & 0 \\
\hline
\end{tabular}

in particular (of the size up to $100-120 \mu \mathrm{m}$ and without posterior spine) were found by KARABIN (1980) and HILlbrichTILKOWSKA (1972) to be a good indicator of the eutrophication rate of the lowland, temperate lakes. There was a significant difference in the occurrence of $K$. cochlearis tecta between the LBS and the LBN in respective months. The contribution of forma tecta to the total population of $K$. cochlearis in the LBN was rather negligible, which confirms the mesotrophic character of this basin (Table 6). The highest number and contribution of forma tecta in $K$. cochlearis population in the LBS occurred in September (Fig. 5), but there was another small but statistically significant increase in the middle of November (Fig. 5). In this month the increases of detritus and probably also of the nanoplankton were reported (see preceding chapter). One must add that, according to Yамамото (1960), forma tecta was not found in the autumn period in the LBS in late 1950's, although forma micracantha with short posterior spine appeared in November in small quantities (YАмамото, 1960).

\section{Summary and Conclusions}

1. The abundance and composition of pelagic species of rotifers were studied from September to December, 1980 at both $\mathrm{LBN}$ and LBS, i.e. the mesotrophic, deep northern basin and highly eutrophic, shallow, southern basin of Lake Biwa. The samples were taken monthly and they were integrated for the whole water column at

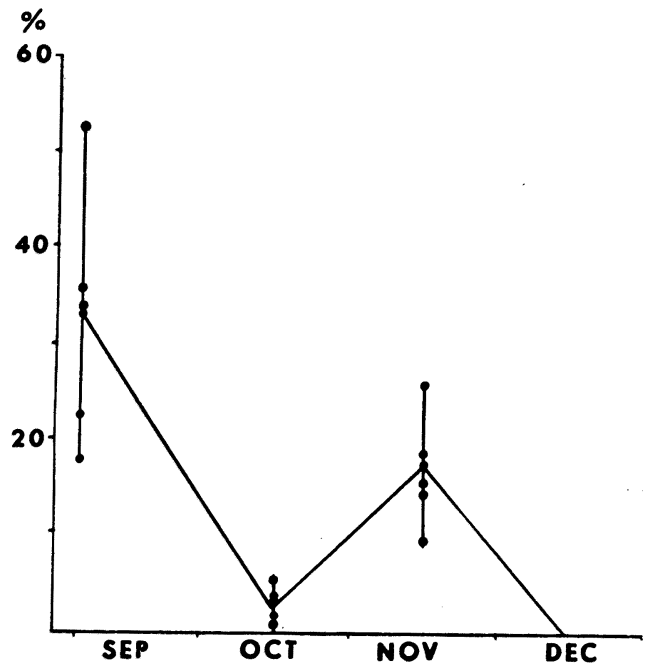

Fig. 5. The percentage of forma tecta in the total numbers of Keratella cochlearis in the southern basin of Lake Biwa from September to December 1980. The vertical lines indicate the range for stations.

six stations in the LBS, and for the epilimnion $(0-15 \mathrm{~m}$ in depth), at two stations in the LBN.

2. The period of the studies was characterised by two phenomena: 1) the steady decrease of temperature and 2) the increase of turbidity (cooling period) coupled with the shift from the bloom of such green algae as Staurastrum dorsidentiferum and Pediastrum biwae in September to the bloom of such diatoms as Fragilaria crotonensis and Melosira sp. div. in December. A noticeable increase in abundance of detritus was also noted in both months October and November in the LBS, probably due to the resuspension of the bottom sediment. Also, some increase in nanoplanktonic chlorophyll $a$ content was reported in other sources.

3. A significant difference was observed between both basins in the abundance of seston and species density of the rotifers. That is to say, TSI (CARLSON, 1977) based upon the Secchi disc readings was $43-26$, the densities of rotifers $30-300$ ind. $\cdot l^{-1}$ in the LBN, while the TSI was 40-75 
and the densities were $300-3,000$ ind. $\cdot l^{-1}$ in the LBS. Further, the contribution of Keratella cochlearis especially forma tecta which is regarded as a good indicator of eutrophy and hypertrophy was up to $50 \%$ in the LBS and up to $1 \%$ for the LBN.

4. The abundance of rotifers found in Lake Biwa in autumn 1980 as well as in the same period of 1978 and 1979 by ICHISE and WaKabayashi (1980) was at least several to one order of magnitude higher than that found by Yамамото (1967, 1968) in the autumn periods from 1965 to 1967. The values of abundance reported in the LBS in the 1965-1967 ranged from 10 to 600 ind. $\cdot l^{-1}$, while in 1980 from 100 3000 ind. $\cdot l^{-1}$. Due to the different method for plankton collection the values concerned 1965-1967 years were doubled before comparing with the actual ones, but even if so considered the difference is significant. The increased abundance of rotifers is undoubtedly the effect of the accelerated eutrophication which takes place in the both basins of Lake Biwa, although rates were different. According to KARABIN (1980) the numbers of rotifers higher than 500 ind. $\cdot l^{-1}$ in epilimnion are usually found in the eutrophic, lowland temperate lakes and those higher than 2000 ind. $\cdot l^{-1}$ are of the hypertrophic ones. So high value in the abundance was noted in the LBS during the last autumn. The process of eutrophication in this basin was significantly faster than in the LBN due to the obvious difference in the antropogenous impact and depth-volume relation.

5. Some of the changes in relative abundance and the period of occurrence of the particular species in the compared periods (1965-1967 and 1980) can also be connected with the process of eutrophication. There was the significant increase of abundance of Keratella cochlearis, Polyarthra vulgaris and Pol. dolichoptera in both basins, K. quadrata and Brachionus calyciflorus in November and December in the LBS and Collotheca pelagica in the whole study period in the LBN. All these species are fine particle feeders with the preference to detritus and bacteria like $K$. cochlearis and Coll. pelagica or to small algae like $K$. quadrata and $B r$. calyciflorus. Polyarthra sp. div. can also grasp actively the food items and feed on small algae and flagellates.

6. The changing thermic and trophic conditions (see point 2) affected the succession of rotifers from September to December. The fine particle filter feeders like $K$. cochlearis and $K$. quadrata dominated in September and December respectively, while in November dominated the grasping feeders like Pol. vulgaris and Pol. dolichoptera. Also in November, the noticeable increase of the numbers of $K$. cochlearis forma tecta is observed in the LBS. Judging from the tentative data on the detritus abundance and original data collected a year ago on the dynamics of the chlorophyll $a$ in the small size up to $25 \mu \mathrm{m}$ fraction of the seston, it can be said that starting from October the significant increase of the food particles available for rotifers takes place. This is why, irrespective of the unfavorable thermic conditions (cooling of the lake water), favorable trophic conditions appeared in the late autumn in Lake Biwa which enable the rotifers to occur in relatively high number till December.

\section{Acknowledgements}

This study was supported by the Japan Society for Promotion of Sciences and by the Otsu Hydrobiological Station, Kyoto University. The author wishes to thank Prof. Taizo MiUra for his generous help in arrangement of this study and Dr. Tetsuya NARITA for his valuable assistance during the research and for his permission to use the unpublished data on the concentrations of chlorophyll $a$. The author appreciates very much also the friendship and criticism from all colleagues of Otsu Hydrobiological Station.

\section{摘 要}

1980 年 9 月から 12 月にかけて琵琶湖の浮遊性ワム シ類の密度を調査した結果, $100 \sim 3,000$ 個体 $\cdot l^{-1}$ の 值が得られ，乙の値は山元 $(1967,1968)$ の得た 10 ～600 個体 $\cdot l^{-1}$ の值よりも藷しく大きかった。 個体倠 密度の增加はつぎのような租類で認められた：1) Keratella cochlearis, Collotheca pelagica, Bra- 
chionus spp. および K. quadrata のような小また はは微粒子摂食者, 2) Polyarthra vulgaris および $P$. dolichoptera のような graspers. このような長 期間にわたる变化は琵琶湖の富栄養化が促進されたて との証拠であろう。

琵琶湖の 2 つの湖盆の間の栄養度の違いは, 南湖の 方が北湖にくらべて，1）ワムシ類の密度が高い，2）

K. cochlearis の占める割合が大きい，3）栄養度指 数 (Trophic State Index) が高い, という点に現れ ている.

秋の水温の低下と平行して起とった緑藻から珪藻へ のブルームの移行の際には, 粒子の大きさの違いにも とづく食物選択と関係して, つぎのような優占種の遷 移が起しった：K. cochlearis $\rightarrow$ Polyarthra spp. $\rightarrow$ K. quadrata. 11 月には $K$. cochlearis f. tecta の 数が著しく增大した。

\section{References}

Botrell, H. H., A. Duncan, Z. M. Gliwicz, E. Grygierek, A. Herzig, A. HillbrichtIlkowsKa, H. Kurosawa, P. LARSSON and T. Weglenska (1976) : A review of some problems in zooplankton production studies. Norv. J. Zool., 27: 419-456.

Carlson, R.E. (1977) : A trophic state index for lakes. Limnol. Oceanogr., 22: 361-369.

Gliwicz, Z.M. (1977) : Food size selection and seasonal succession of filter feeding zooplankton in an eutrophic lake. Ekol pol., 25: $179-225$.

Hillbricht-Ilkowska, A. (1964): The influence of the fish population on the biocenosis of a pond using rotifer fauna as an illustration. Ekol. pol., 12: 453-503.

Hillbricht-Ilkowska, A. (1972) : Morphological variation of Keratella cochlearis (Gosse), Rotatoria, in several Masurian Lakes of different trophic level. Pol. Arch. Hydrobiol., 19: 253-264.

Hillbricht-Ilkowska, A. (1978) : Ecological indices of change in temperate aquatic ecosystems. In: N. Duncan and J. Rzóska (eds), Land Use Impact on Lake and Reservoir Ecosystems. Proc. Int. Symp. MAB-5, 26 May-2 June, Warsaw. Facultas Verlag, Wien. 35-66.

Hillbricht-Illowska, A. and T. Weglenska (1973) : Experimentally increased fish stock in the pond type Lake Warniak. VII. Numbers, biomass and production of zooplankton. Ekol. pol., 21: 533-552.

Ichise, S. and T. Wakaвayashi (1980): The seasonal succesion of plankton in southern part of Lake Biwa and biological estimation of water quality. Rep. Shiga Pref. Inst.
Pub. Hlth. and Environ. Sci., 15: 53-67. Inoue, Y., S. Iwai, Ineda and T. Kunimatsu (1980): Eutrophication of Lake Biwa. Nutrient load and ecological model. XXI Int. Congress of Limnology, Kyoto 24-31 August, 1980. Abstract, 59-60.

Karabin, A. (1980) : The changes of the abundance and composition of zooplankton along the eutrophication process in Masurian Lakes, Poland. Ph. Doctor's Thesis. Inst. of Ecology, Pol. Ac. Sci. pp 92.

LANDER, L. (1976) : Eutrophication of lakes. FAO Papers, December 1976. ICP/CEP 210, p. 78.

Mori, S. (1980): An Introduction to Limnology of Lake Biwa. Kyoto. p. 70.

Negoro, K. (1967) : First report of the regular survey of Lake Biwa. (Oct. 1965-Dec. 1966). II. Plankton in general and phytoplankton. Mem. Fac. Sci. Kyoto Univ. Ser. Eiol., 1: 41-61.

Negoro, K. (1968) : Second report of regular limnological survey of Lake Biwa (1967). I. Plankton in general and phytoplankton. Mem. Fac. Sci. Kyoto Univ. Ser. Biol., 2: 7291.

Pejler, B. (1980): Variation in the genus $K e$ ratella. Hydrobiologia (den Haag) 73: 207203.

Pourriot, R. (1965): Recherches sur l'écologie des Rotifers. Vie et Milieu, Suppl., 21: 1125.

WaKabayashi, T. and S. Ichise (1980): The seasonal succession of planktons in northern part of Lake Biwa in 1979. Rep. Shiga Pref. Inst. Pub. Hlth and Environ. Sci., 15: 45-52.

Y амдмото, K. (1980): Plankton Rotatoria in Japanese inland waters. Hydrobiologia (den Haag), 16: 464-411.

Yамамото, K. (1967) : First report of the regular limnological survey of Lake Biwa (Oct. 1965-Dec. 1966). III. Zooplankton. Mem. Fac. Sci. Kyoto Univ. Ser. Biol., 1: 6277.

Yамамото, K. (1968): Second report of the regular limnological survey of Lake Biwa (1967). II. Zooplankton. Mem. Fac. Sci. Kyoto Univ. Ser. Biol., 2: 92-106.

Yamamoтo, K. (1960): The rotifers found in the plankton samples in Lake Biwa-kó (in Japan).

(Author's address: Anna Hillbricht-Ilkowska, Institute of Ecology, Polish Academy of Sciences, Dziekanów Leśny, 05-092 Łomianki, Poland).

Accepted: 15 December 1.982 